\title{
Dietary Supplementation with Phytase and Protease Improves Growth Performance, Serum Metabolism Status, and Intestinal Digestive Enzyme Activities in Meat Ducks
}

\author{
Junjie Jiang, Hao Wu, Dan Zhu, Jiameng Yang, Jianying Huang, Shuo Gao and Gang Lv * \\ Institute of Livestock and Poultry, Tongwei Co., Ltd., Chengdu 610041, China; Jiangjj04@tongwei.com (J.J.); \\ Wuh05@tongwei.com (H.W.); Zhud@tongwei.com (D.Z.); Yangjm01@tongwei.com (J.Y.); \\ Huangjy02@tongwei.com (J.H.); Gaos04@tongwei.com (S.G.) \\ * Correspondence: Lvg@tongwei.com; Tel./Fax: +86-28-85150888
}

Received: 14 January 2020; Accepted: 5 February 2020; Published: 8 February 2020

Simple Summary: Nowadays, as demand for reducing feed waste is increasing, it is imperative to apply enzyme preparations to achieve maximum effectiveness of feed. This study investigated the effects of dietary supplementation with phytase and protease in low-energy and low-protein diet on the growth performance, serum metabolism parameters, and intestinal digestive enzyme activities of meat ducks, which provided new insights into the positive roles of phytase and protease in growth performance, serum metabolism parameters, and intestinal digestive enzyme activities. This study contributes to the improvement in appropriate applications of exogenous enzyme preparations for poultry industry.

\begin{abstract}
Two experiments were conducted to investigate the effects of dietary supplementation with protease and phytase on growth performance, serum physiochemical parameters, and activities of digestive enzymes in jejunal digesta of meat ducks. Experiment 1 was carried out to determine the effects of different protease or phytase on growth performance, serum physiochemical parameter, and activities of digestive enzymes in jejunal digesta of meat ducks to select the optimal phytase or protease. According to the hatching age and initial weight, a total of 5040 Cherry Valley ducks (15 days of age) were randomly assigned into six treatments. Treatments included a basal control diet $(\mathrm{CON})$ and 5 basal diets supplemented with different enzyme preparations, which were phytase preparation $\mathrm{A}(\mathrm{PA}, 160 \mathrm{~g} / \mathrm{t})$, phytase preparation $\mathrm{B}(\mathrm{PB}, 800 \mathrm{~g} / \mathrm{t})$, protease preparation $\mathrm{A}(\mathrm{PTA}, 80 \mathrm{~g} / \mathrm{t})$, protease preparation $B(P T B, 300 \mathrm{~g} / \mathrm{t}$ ) and protease preparation C (PTC, $200 \mathrm{~g} / \mathrm{t})$. The enzyme activities were as follows: Phytase A and B as well as protease A, B, and C were 50,000, 10,000, 250,000, 50,000, and 60,000 U/g, respectively. Each treatment had 7 replicates with 120 meat ducks per replicate. Experiment 1 lasted for 28 days. The results showed that: compared with the CON group, the PA group significantly decreased contents of serum phosphorus and calcium $(p<0.05)$, and the PTA, PTB, and PTC groups had higher activities of trypsin in jejunal digesta $(p<0.05)$, and the activity of jejunal chymotrypsin in PTA group was greater $(p<0.05)$. Experiment 2 was carried out to determine the effects of dietary supplementation with protease and phytase in low-energy and low-protein diet on growth performance, serum physiochemical parameters, and activities of digestive enzymes in jejunal digesta of meat ducks. According to the hatching age and initial weight, a total of 5760 Cherry Valley ducks (15 days of age) were randomly assigned into four treatments on the basis of a trial of $2 \times 2$ factorial design. Treatments included a basal control diet (PC), basal diet supplemented with enzymes (PCE), low-energy and low-protein diet (LEP), and low-energy and low-protein diet supplemented with enzymes (LEPE), the nutrient levels of energy and CP of basal diet were $2747.2 \mathrm{cal} \cdot \mathrm{ME} / \mathrm{kg}$ and $16.80 \%$, respectively, and the nutrient levels of energy and CP of low-energy and low-protein diet decreased $45.90 \mathrm{kcal} \cdot \mathrm{ME} / \mathrm{kg}$ and $0.52 \%$ on the basis of basal diet, respectively. According to the results
\end{abstract}


of experiment 1, phytase A and protease A were determined as the optimal enzyme combination of Experiment 2, and additional dosage of which were identical with Experiment 1. Each treatment had 6 replicates with 240 meat ducks per replicate. Experiment 2 lasted for 28 days. The results showed that: compared with PC and LEP groups, PCE and LEPE groups had higher final weight and average daily gain (ADG) $(p<0.05)$, higher activities of trypsin and chymotrypsin in jejunal digesta $(p<0.05)$, lower contents of serum calcium and phosphorus as well as higher levels of high-density lipoprotein in the serum $(p<0.05)$. In conclusion, dietary supplementation with phytase and protease in different energy and protein diets could increase digestive enzymes in jejunal digesta, effect serum physiochemical parameters, improve metabolic status, and increase the growth performance of meat ducks. Meanwhile, with the dietary supplementation with phytase and protease in the lower energy and protein diet, the growth performance could reach to the degree of the higher energy and increased protein diet, but without the addition of phytase and protease.

Keywords: meat ducks; growth performance; phytase; protease; low-energy and low-protein diet

\section{Introduction}

Phytate widely exists in plant feed and is abruptly stressful in the process of poultry's digestion and absorption [1], since phytate could be combined with various nutrients (protein, fat, and minerals) in feed or digestive enzymes ( $\alpha$-amylase, trypsin, and pepsin) in animals' gastrointestinal tract to form stable complexes [2], which in turn affects diverse aspects of function in the intestine, including lower activities of epithelial brush border enzymes and subsequent decrease in the digestibility of nutrients [3], thus reducing growth performance of poultry. Phytase, as a kind of common enzyme preparation in feed industry, was proven to be used as a growth-promoting agent on poultry [4], which has been repeatedly shown to have beneficial effects on removing chelation between phytic acid and protein in gastrointestinal tract of poultry [5]. Over the past two decades, the addition of exogenous phytases to poultry diets has become a standard practice. Recently, studies have further proposed that phytase could not only prevent excessive waste of nutrients in feed, but also played an essential role in reducing environmental pollution [4-6].

The ratio digestive tract to body length of poultry is shorter (about 4:1) compared with livestock, resulting in low endogenous digestive enzyme activity and sub-optimal nutrients digestibility [4]. Poultry enhancing or maintaining erepsin and trypsin activities in the gastrointestinal tract during the two weeks after hatching requires a long adaption period, which may result in serious economic losses to the poultry industry [7]. Moreover, low digestive enzyme activities in the gastrointestinal tract in turn affect diverse aspects of digestive function in the intestine of poultry, including intestinal inflammation, villous atrophy, and crypt hyperplasia [8]. Protease plays an important role in the food industry and has been used as a kind of enzyme addition for decades [9]. Concerned studies have previously demonstrated that dietary supplementation with exogenous protease could make up for the deficiency of endogenous protease and improve the digestibility of nutrients in feed as well as growth performance in poultry $[10,11]$. Meanwhile, protease might be helpful to hydrolyze anti-nutritional factors such as lectin and trypsin inhibitors, improving the utilization efficiency of amino acids in poultry [12].

In the livestock and poultry industry, the basic function of exogenous enzyme preparations is to improve the nutrition values of diets. In addition, dietary supplementation with exogenous enzyme preparation could also reduce the variability between the calculated and analyzed nutrient compositions [13]. Furthermore, dietary supplementation with exogenous phytase in low-energy diets or protease in low-protein diets has been proven to exert beneficial influences on the growth performance of poultry, including increases in feed intake and body weight [13-15]. China is the main production area of ducks, most of which are meat ducks, and there is a great waste of feeds for meat 
ducks because of insufficient endogenous enzyme secretions and subsequent poor digestibility of feeds. Although the various functions of exogenous phytase and protease have received extensive attention in broilers, there were few studies on how to appropriately apply in exogenous phytase and protease in feeds of meat ducks, and little is known about whether diets supplemented with exogenous phytase and protease in low-energy and low-protein diets could reach the degree of the a higher energy and increased protein diet, but without dietary supplementation with phytase and protease. Therefore, the objective of this study is to further evaluate the effects of dietary phytase and protease on growth performance, serum metabolism status, and intestinal digestive enzyme activities in meat ducks.

\section{Materials and Methods}

All procedures of animal experiments were carried out on the basis of protocols approved by the Animal Care Advisory Committee of Institute of Livestock and Poultry, Tongwei Co., Ltd., Chengdu, China (no. 20190610).

The phytase A (provided per gram of phytase 50000 units) and phytase B (provided per gram of phytase 10,000 units) were provided by DSM (China) Co., Ltd., Shanghai, China and Guangdong Yiduoli biology technolohy Co., Ltd., Zhuhai, China, respectively. The protease A (provided per gram of protease 250,000 units), protease B (provided per gram of protease 50,000 units) and protease C (provided per gram of protease 60,000 units) were also provided by Shanghai Nutritech Solution Co., Ltd., Shanghai, China, Beijing Smistyle Sci $\&$ Teah development Co., Ltd., Beijing, China, and Qingdao KDN biotech Co., Ltd., Qingdao, China, respectively.

\subsection{Experimental Design and Animal Management (Exp. 1)}

A total of 5040 fifteen-day-old Cherry Valley ducks (commercially purchased from Sichuan Guiliu Poultry Co., Ltd., Chengdu, China) was used in a 28-d experiment. At the beginning of the experiment, ducks were randomly assigned to 6 treatments with 7 replicate pens (60 males and 60 females per pen) on the basis of their initial body weight (BW) and sex. Treatments included a basal control diet (CON) and 5 basal diets supplemented with different enzyme preparations, which were phytase preparation $\mathrm{A}(\mathrm{PA}, 160 \mathrm{~g} / \mathrm{t})$, phytase preparation $\mathrm{B}(\mathrm{PB}, 800 \mathrm{~g} / \mathrm{t})$, protease preparation A (PTA, $80 \mathrm{~g} / \mathrm{t})$, protease preparation $B(\mathrm{PTB}, 300 \mathrm{~g} / \mathrm{t}$ ) and protease preparation C (PTC, $200 \mathrm{~g} / \mathrm{t})$.

All ducks were reared in cages $(4.0 \times 3.0 \times 0.8 \mathrm{~m})$ in a temperature-controlled room with a $24 \mathrm{~h}$ constant light schedule and had free access to water and feed throughout the experimental period. The basal diet (Table 1) was formulated to meet or exceed the nutrient requirements recommended by the National Research Council [16]. Diets were fed in pellet form, and the diameter of the pellets was $3.5 \mathrm{~mm}$. 
Table 1. Compositions and nutrient contents of the experiment basal diets (air dry basis, \%, Experiment 1).

\begin{tabular}{|c|c|}
\hline Item & $\mathrm{CON}^{7}$ \\
\hline \multicolumn{2}{|l|}{ Ingredients, \% } \\
\hline Maize & 53.89 \\
\hline Wheat flour & 4.50 \\
\hline Wheat bran & 1.58 \\
\hline Rice bran & 5.00 \\
\hline Soybean meal & 13.00 \\
\hline Cottonseed meal & 4.00 \\
\hline Maize germ meal & 8.00 \\
\hline Feather meal & 2.00 \\
\hline Distillers dried grains with solubles & 3.00 \\
\hline Maize gluten meal & 1.70 \\
\hline Calcium carbonate & 1.64 \\
\hline Dicalcium phosphate & 0.59 \\
\hline L-Lysine $\mathrm{HCl}$ & 0.42 \\
\hline DL-Methionine & 0.01 \\
\hline L-Threonine & 0.02 \\
\hline $\mathrm{NaCl}$ & 0.20 \\
\hline Enzyme preparation ${ }^{1}$ & 0.04 \\
\hline Bacitracin methylene disalicylate premix ${ }^{2}$ & 0.01 \\
\hline Preservatives 3 & 0.10 \\
\hline Vitamin premix 4 & 0.10 \\
\hline Mineral premix 5 & 0.20 \\
\hline Total & 100.00 \\
\hline \multicolumn{2}{|l|}{ Calculated Nutrients ${ }^{6}$} \\
\hline ME (kcal/kg) & 2900.00 \\
\hline $\mathrm{CP}(\%)$ & 16.81 \\
\hline $\mathrm{Ca}(\%)$ & 0.84 \\
\hline $\mathrm{TP}(\%)$ & 0.49 \\
\hline $\mathrm{AP}(\%)$ & 0.26 \\
\hline D-Lys & 0.81 \\
\hline D-Met & 0.32 \\
\hline D-Thr & 0.55 \\
\hline D-Trp & 0.20 \\
\hline
\end{tabular}

${ }^{1}$ Provided per gram of enzyme preparation: xylanase, 3500 units. ${ }^{2}$ Provided per kilogram of bacitracin methylene disalicylate premix: bacitracin, $150 \mathrm{mg} .{ }^{3}$ Provided per kilogram of preservatives: sodium diacetate, $1000 \mathrm{mg}$. ${ }^{4}$ Provided per kilogram of diet: vitamin A, $5000 \mathrm{IU}$; vitamin $\mathrm{D}_{3}, 400 \mathrm{IU}$; vitamin E, $10 \mathrm{IU}$; vitamin $\mathrm{K}_{3}, 0.5 \mathrm{mg}$; vitamin $\mathrm{B}_{1}, 2.0 \mathrm{mg}$; vitamin $\mathrm{B}_{6}, 2.5 \mathrm{mg}$; vitamin $\mathrm{B}_{12}, 0.02 \mathrm{mg}$; nicotinic acid, $55 \mathrm{mg}$; pantothenic acid, $10 \mathrm{mg}$; folic acid, $1.0 \mathrm{mg}$; and biotin, $0.1 \mathrm{mg}$. ${ }^{5}$ Provided per kilogram of diet: $60 \mathrm{mg} \mathrm{Fe}\left(\mathrm{FeSO}_{4} \cdot 7 \mathrm{H}_{2} \mathrm{O}\right) ; 8 \mathrm{mg} \mathrm{Cu}\left(\mathrm{CuSO}_{4} \cdot 5 \mathrm{H}_{2} \mathrm{O}\right)$; $60 \mathrm{mg} \mathrm{Zn}\left(\mathrm{ZnSO}_{4} \cdot 7 \mathrm{H}_{2} \mathrm{O}\right) ; 50 \mathrm{mg} \mathrm{Mn}\left(\mathrm{MnSO}_{4} \cdot \mathrm{H}_{2} \mathrm{O}\right) ; 0.1 \mathrm{mg} \mathrm{Se}\left(\mathrm{Na}_{2} \mathrm{SeO}_{3} \cdot 5 \mathrm{H}_{2} \mathrm{O}\right)$; and $0.2 \mathrm{mg} \mathrm{I}(\mathrm{KI}) .{ }^{6}$ Values are calculated. ${ }^{7} \mathrm{CON}$, basal diet; $\mathrm{ME}$, metabolic energy; $\mathrm{CP}$, crude protein; $\mathrm{Ca}$, calcium; $\mathrm{TP}$, total phosphorus; $\mathrm{AP}$, available phosphorus.

\subsection{Sampling and Measurements (Exp. 1)}

The ducks were weighed and feed intake was recorded on days 1 and 28, average daily gain (ADG), average daily feed intake (ADFI), and feed conversion ratio (FCR) were calculated. Dead ducks were collected, weighed, and recorded, and the mortality during the experiment was expressed as a percentage.

On day 29, prior to the morning feeding and following overnight fasting, 4 ducks ( 2 males and 2 females) with the average BW in each pen were chosen and bled. Blood samples were collected from the precaval vein into nonheparinized vacuum tubes. Briefly, after centrifugation $(3500 \times g$ for $10 \mathrm{~min}$ at $4{ }^{\circ} \mathrm{C}$ ), serum samples were collected and stored at $-20{ }^{\circ} \mathrm{C}$ for serum parameters analysis. After bleeding, the same ducks were sacrificed by cervical dislocation, and the abdomen was immediately unfolded for the collection of gut sections. The entire small intestine was removed and cut into three 
segments: duodenum, jejunum, and ileum. Subsequently, $20 \mathrm{~cm}$ of jejunum was immediately isolated, which was gently squeezed to collect the jejunum digesta sample and stored at $-20^{\circ} \mathrm{C}$ for activity of digestive enzyme analysis.

Serum phosphorus and calcium levels were assayed using commercially available kits (Nanjing Jiancheng Bioengineering Institute, Nanjing, China), and the catalog numbers of which were C006-1-1 and C004-2-1, respectively. The jejunal digesta samples, were weighed, and then broken with an ultrasonic cell disruptor with the addition of $0.9 \%$ physiological saline in the ice bath. After centrifugation, the supernatant protein concentration was assayed using a protein quantification kit (Nanjing Jiancheng Bioengineering Institute, Nanjing, China) as the protein standard, and the catalog number of which was A045-2-2. Subsequently, activities of trypsin and chymotrypsin in the supernatant solution were analyzed using commercial kits (Nanjing Jiancheng Bioengineering Institute, Nanjing, China) according to the manufacturer's instruction, and the catalog numbers of which were A080-2-2 and A080-3-1, respectively.

\subsection{Statistical Analysis (Exp. 1)}

Growth performance data were analyzed by ANOVA using the t-test procedure of SAS 9.0 software (SAS, Raleigh, NC, USA) with the pen being the experimental unit $(n=7)$. All other data were also analyzed by ANOVA using the $t$-test procedure of SAS 9.0 software (SAS Inst. Inc., Cary, NC, USA) with average data of 4 sampled ducks per pen as the experimental unit $(n=7)$. The results were presented as mean and standard error of means (SEM). Probability values less than 0.05 were considered significant, whereas probability values less than 0.10 was considered a tendency.

\subsection{Experimental Design and Animal Management (Exp. 2)}

A total of 5760 fifteen-day-old Cherry Valley ducks (commercially purchased from Sichuan Guiliu Poultry Co., Ltd., Chengdu, China) was used in a 28-day experiment on the basis of a trial of $2 \times 2$ factorial design. At the beginning of the experiment, ducks were randomly assigned to 4 treatments with 6 replicate pens (120 males and 120 females per pen) on the basis of their initial BW and sex. Treatments included a basal control diet (PC), basal diet supplemented with enzymes (PCE), low-energy and low protein diet (LEP) and low-energy and low-protein diet supplemented with enzymes (LEPE). According to the results of experiment 1, phytase A and protease A were determined as the optimal enzyme combination, and additional dosage of which were identical with experiment 1.

All ducks were reared in cages $(6.0 \times 4.0 \times 0.8 \mathrm{~m})$ in a temperature-controlled room with a $24 \mathrm{~h}$ constant light schedule and had free access to water and feed throughout the experimental period. The basal diet (Table 2) was formulated to meet or exceed the nutrient requirements recommended by the National Research Council [16], the nutrient levels of energy and CP of basal diet were $2747.2 \mathrm{cal} \cdot \mathrm{ME} / \mathrm{kg}$ and $16.80 \%$, respectively, and the nutrient levels of energy and $\mathrm{CP}$ of low-energy and low-protein diet decreased $45.90 \mathrm{kcal} \cdot \mathrm{ME} / \mathrm{kg}$ and $0.52 \%$ on the basis of basal diet, respectively. Diets were fed in pellet form, and the diameter of the pellets was $3.5 \mathrm{~mm}$. 
Table 2. Compositions and nutrient contents of the experiment basal diets (air dry basis, \%, Experiment 2).

\begin{tabular}{|c|c|c|}
\hline Item & $\mathrm{PC}^{7}$ & LEP \\
\hline \multicolumn{3}{|l|}{ Ingredients, $\%$} \\
\hline Maize & 53.02 & 53.42 \\
\hline Wheat flour & 5.00 & 5.00 \\
\hline Wheat bran & 13.06 & 15.128 \\
\hline Soybean meal & 9.40 & 7.30 \\
\hline Cottonseed meal & 5.00 & 5.00 \\
\hline Distillers dried grains with solubles & 10.00 & 10.00 \\
\hline Soybean oil & 0.50 & 0.00 \\
\hline Calcium carbonate & 1.60 & 1.61 \\
\hline Dicalcium phosphate & 0.55 & 0.54 \\
\hline L-Lysine $\mathrm{HCl}$ & 0.65 & 0.725 \\
\hline DL-Methionine & 0.16 & 0.173 \\
\hline L-Threonine & 0.11 & 0.129 \\
\hline L-Valine & 0.00 & 0.025 \\
\hline $\mathrm{NaCl}$ & 0.40 & 0.40 \\
\hline Preservatives ${ }^{1}$ & 0.10 & 0.10 \\
\hline Montmorillonite premix ${ }^{2}$ & 0.10 & 0.10 \\
\hline Antioxidants ${ }^{3}$ & 0.05 & 0.05 \\
\hline Vitamin premix 4 & 0.10 & 0.10 \\
\hline Mineral premix 5 & 0.20 & 0.20 \\
\hline Total & 100.00 & 100.00 \\
\hline \multicolumn{3}{|l|}{ Calculated Nutrients ${ }^{6}$} \\
\hline $\mathrm{ME}(\mathrm{kcal} / \mathrm{kg})$ & 2701.30 & 2747.20 \\
\hline $\mathrm{CP}(\%)$ & 16.28 & 16.80 \\
\hline $\mathrm{Ca}(\%)$ & 0.78 & 0.78 \\
\hline $\mathrm{TP}(\%)$ & 0.48 & 0.48 \\
\hline $\operatorname{AP}(\%)$ & 0.25 & 0.25 \\
\hline D-Lys & 0.90 & 0.90 \\
\hline D-Met & 0.41 & 0.41 \\
\hline D-Thr & 0.59 & 0.59 \\
\hline D-Trp & 0.14 & 0.14 \\
\hline
\end{tabular}

${ }^{1}$ Provided per kilogram of preservatives: sodium diacetate, $1000 \mathrm{mg}$. ${ }^{2}$ Provided per kilogram of montmorillonite premix: montmorillonite, 850 g. ${ }^{3}$ ENDOX ${ }^{\mathrm{TM}}$ (Kemin industries Co., Ltd., Zhuhai, China). Butyl hydroxy anisd: 1.8\%; Ethoxyquin: $2.7 \%{ }^{4}$ Provided per kilogram of diet: vitamin A, $5000 \mathrm{IU}$; vitamin $\mathrm{D}_{3}, 400 \mathrm{IU}$; vitamin E, $10 \mathrm{IU}$; vitamin $\mathrm{K}_{3}, 0.5 \mathrm{mg}$; vitamin $\mathrm{B}_{1}, 2.0 \mathrm{mg}$; vitamin $\mathrm{B}_{6}, 2.5 \mathrm{mg}$; vitamin $\mathrm{B}_{12}, 0.02 \mathrm{mg}$; nicotinic acid, $55 \mathrm{mg}$; pantothenic acid, $10 \mathrm{mg}$; folic acid, $1.0 \mathrm{mg}$; and biotin, $0.1 \mathrm{mg} .{ }^{5}$ Provided per kilogram of diet: $60 \mathrm{mg} \mathrm{Fe}\left(\mathrm{FeSO}_{4} \cdot 7 \mathrm{H}_{2} \mathrm{O}\right) ; 8 \mathrm{mg} \mathrm{Cu}$ $\left(\mathrm{CuSO}_{4} \cdot 5 \mathrm{H}_{2} \mathrm{O}\right) ; 60 \mathrm{mg} \mathrm{Zn}\left(\mathrm{ZnSO}_{4} \cdot 7 \mathrm{H}_{2} \mathrm{O}\right) ; 50 \mathrm{mg} \mathrm{Mn}\left(\mathrm{MnSO}_{4} \cdot \mathrm{H}_{2} \mathrm{O}\right) ; 0.1 \mathrm{mg} \mathrm{Se}\left(\mathrm{Na}_{2} \mathrm{SeO}_{3} \cdot 5 \mathrm{H}_{2} \mathrm{O}\right)$; and $0.2 \mathrm{mg} \mathrm{I}(\mathrm{KI})$.

${ }^{6}$ Values are calculated. ${ }^{7} \mathrm{PC}$, basal diet; LEP, basal diet in low and protein levels.

\subsection{Sampling and Measurements (Exp. 2)}

All sampling and growth performance measuring procedures used were similar to those previously described for exp. 1.

Serum glucose, cholesterol, low-density lipoprotein, high-density lipoprotein, urea nitrogen, phosphorus and calcium levels as well as aspartate aminotransferase, alanine aminotransferase, and alkaline phosphatase activities were assayed using commercially available kits (Nanjing Jiancheng Bioengineering Institute, Nanjing, China), and the catalog numbers of which were F006-1-1, A111-1-1, A113-1-1, A112-1-1, C013-2-1, C006-1-1, C004-2-1, C010-2-1, C009-1-1, and A059-2-2, respectively. The jejunal digesta samples, were weighed, and then broken with an ultrasonic cell disruptor with the addition of certain saline in the ice bath. After centrifugation, the supernatant protein concentration was assayed using a protein quantification kit (Nanjing Jiancheng Bioengineering Institute, Nanjing, China) as the protein standard, and the catalog number of which was A045-2-2. Subsequently, activities of trypsin and chymotrypsin in the supernatant solution were analyzed using commercial kits (Nanjing Jiancheng Bioengineering Institute, Nanjing, China) according to the manufacturer's instruction, and the catalog numbers of which were A080-2-2 and A080-3-1, respectively. 


\subsection{Statistical Analysis (Exp. 2)}

Growth performance data were analyzed by two-way ANOVA using the Generalized Linear Models procedure of SAS 9.0 software (SAS, Raleigh, NC, USA) with pen as the experimental unit $(n=6)$. All other data were also analyzed by two-way ANOVA using the Generalized Linear Models procedure of SAS 9.0 software)(SAS, Raleigh, NC, USA) with average data of 4 sampled ducks per pen as the experimental unit $(n=6)$. The statistical model included the main effects of nutrient level, enzyme, and their interaction. The results were presented as mean and SEM. Statistical differences among treatment were determined by Duncan's multiple-range test. For significance determination, the $\alpha$-level was set as 0.05 . Probability values less than 0.05 were considered significant, whereas probability values less than 0.10 was considered a tendency..

\section{Results}

\subsection{Growth Performance (Exp. 1)}

As shown in Table 3, no differences in growth performance were detected among ducks of the CON, PA, PB, PTA, PTB, and PTC groups $(p>0.10)$, but meat ducks fed diets supplemented with phytase or protease exhibited numerically higher ADG and ADFI than those fed the CON diet $(p>0.10)$.

Table 3. Effects of different protease or phytase on growth performance in ducks ${ }^{1}$.

\begin{tabular}{ccccccccc}
\hline Item & CON $^{2}$ & PA & PB & PTA & PTB & PTC & SEM $^{3}$ & $p$-Value \\
\hline Initial weight, g & 519.11 & 519.11 & 519.11 & 519.15 & 519.18 & 519.17 & 23.0 & 0.90 \\
Final weight, g & 3175.11 & 3193.32 & 3198.34 & 3223.66 & 3200.01 & 3208.03 & 180.0 & 0.73 \\
ADG, g/d & 91.59 & 92.21 & 92.39 & 93.26 & 92.24 & 92.72 & 0.60 & 0.64 \\
ADFI, g/d & 188.60 & 190.78 & 194.18 & 188.72 & 192.59 & 189.16 & 2.74 & 0.53 \\
FCR & 2.06 & 2.07 & 2.10 & 2.02 & 2.08 & 2.04 & 0.04 & 0.45 \\
Mortality, \% & 3.10 & 1.60 & 1.90 & 3.20 & 0.90 & 1.90 & 0.89 & 0.54 \\
\hline
\end{tabular}

${ }^{1}$ Means represent 7 pens of ducks with 120 birds per pen $(n=7) .{ }^{2} \mathrm{CON}$, basal diet; PA, phytase A; PA, phytase B; PTA, protease A; PTB, protease $B$; PTC, protease $C$; $A D G$, average daily gain; $A D F I$, average daily feed intake; FCR, feed conversion ratio. ${ }^{3}$ Standard error of the means.

\subsection{Serum Physiochemical Parameters and Digestive Enzyme Activities (Experiment 1)}

Table 4 presents the differences in serum physiochemical parameters and digestive enzyme activities of jejunal digesta among the 6 groups. Compared with the CON group, the PA group significantly decreased contents of serum phosphorus and calcium $(p<0.05)$, and the PTA, PTB, and PTC groups had higher activities of trypsin in jejunal digesta $(p<0.05)$, and the activity of jejunal chymotrypsin in PTA groups was greater $(p<0.05)$.

Table 4. Effects of different protease or phytase on serum physiochemical parameters and digestive enzyme activities in ducks ${ }^{1}$.

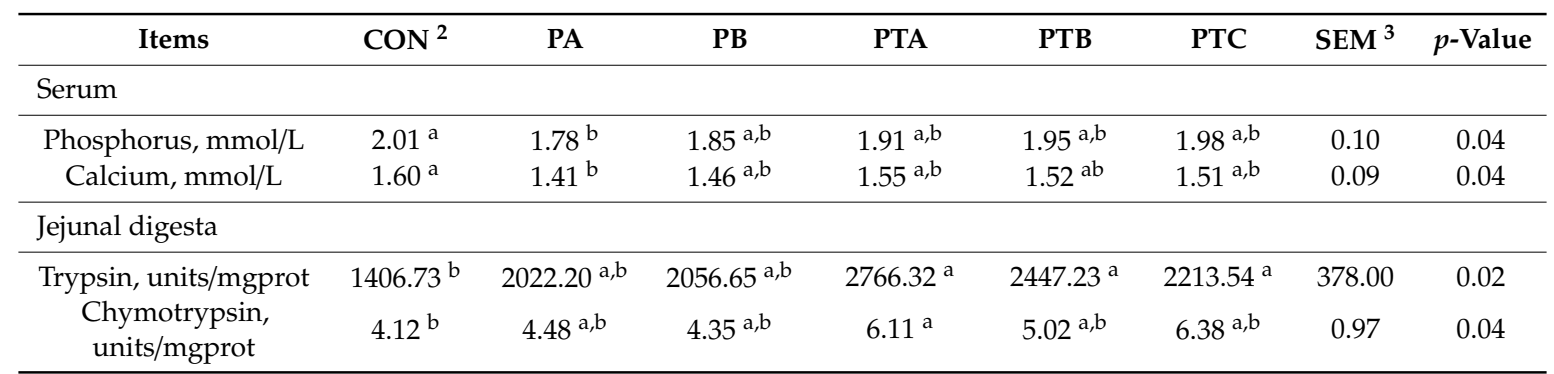

a,b Means in a row with different letter differ $(p<0.05) .{ }^{1}$ Means represent 7 pens of ducks with 4 birds per pen $(n=7) .{ }^{2} \mathrm{CON}$, basal diet; PA, phytase A; PA, phytase B; PTA, protease A; PTB, protease B; PTC, protease C. ${ }^{3}$ Standard error of the means. 


\subsection{Growth Performance (Exp. 2)}

The growth performance is given in Table 5. Dietary supplementation with phytase and protease had higher final weight and ADG compared with groups without supplementation of phytase and protease $(p<0.05)$, and there were interactive trend effects on ADG between nutrients levels and supplementation of enzymes $(p<0.10)$. In addition, dietary supplementation with phytase and protease tended to decrease FCR compared with groups without supplementation of phytase and protease $(p<0.10)$.

Table 5. Effects of protease and phytase in low energy and protein diet on growth performance in ducks ${ }^{1}$.

\begin{tabular}{|c|c|c|c|c|c|c|c|c|}
\hline Items & $\mathrm{PC}^{2}$ & PCE & LEP & LEPE & SEM $^{3}$ & $p^{*}$ & $p^{\#}$ & $p^{+}$ \\
\hline Initial weight, $g$ & 727.50 & 712.50 & 711.20 & 717.20 & 26.60 & 0.81 & 0.89 & 0.39 \\
\hline Final weight, $g$ & $3241.00^{b}$ & $3366.00^{a}$ & $3243.00^{b}$ & $3370.00^{\mathrm{a}}$ & 73.23 & 0.20 & 0.04 & 0.19 \\
\hline ADG, $\mathrm{g} / \mathrm{d}$ & $89.78^{b}$ & $94.78^{\mathrm{a}}$ & $90.40^{\mathrm{b}}$ & $91.00^{\mathrm{a}}$ & 2.85 & 0.19 & 0.02 & 0.08 \\
\hline ADFI, g/d & 194.39 & 197.33 & 194.64 & 185.64 & 10.15 & 0.28 & 0.57 & 0.26 \\
\hline FCR & 2.16 & 2.08 & 2.15 & 2.04 & 0.10 & 0.56 & 0.06 & 0.75 \\
\hline Mortality, \% & 1.84 & 2.14 & 3.29 & 3.00 & 0.19 & 0.29 & 0.99 & 0.78 \\
\hline
\end{tabular}

\subsection{Serum Physiochemical Parameters and Digestive Enzyme Activities (Experiment 2)}

As shown in Table 6, compared with groups without supplementation of phytase and protease, dietary supplementation with phytase and protease had higher serum contents of high-density lipoprotein as well as lower serum levels of phosphorus and calcium $(p<0.05)$, in addition, supplementation of phytase and protease decreased activities of trypsin and chymotrypsin compared with groups without supplementation of phytase and protease $(p<0.05)$. However, there were no interactive trend effects on serum physiochemical parameters and digestive enzyme activities between nutrients levels and supplementation of enzymes $(p>0.10)$.

Table 6. Effects of protease and phytase in low energy and protein diet on serum physiochemical parameters and digestive enzyme activities in ducks ${ }^{1}$.

\begin{tabular}{|c|c|c|c|c|c|c|c|c|}
\hline Items & $\mathrm{PC}^{2}$ & PCE & LEP & LEPE & SEM $^{3}$ & $p *$ & $p^{\#}$ & $p^{+}$ \\
\hline Glucose, mmol/L & 12.22 & 11.61 & 11.70 & 11.80 & 2.59 & 0.86 & 0.79 & 0.72 \\
\hline Low-density lipoprotein, mmol/L & 0.67 & 0.76 & 0.76 & 0.83 & 0.15 & 0.13 & 0.13 & 0.90 \\
\hline High-density lipoprotein, $\mathrm{mmol} / \mathrm{L}$ & $1.63^{b}$ & $2.40^{\mathrm{a}}$ & $1.72^{b}$ & $2.53^{\mathrm{a}}$ & 0.60 & 0.51 & 0.01 & 0.90 \\
\hline Calcium, $\mathrm{mmol} / \mathrm{L}$ & $1.54^{\mathrm{b}}$ & $1.45^{\mathrm{a}}$ & $1.54^{\mathrm{b}}$ & $1.45^{\mathrm{a}}$ & 0.10 & 0.93 & 0.01 & 0.99 \\
\hline Aspartate aminotransferase, units/L & 17.42 & 16.22 & 16.99 & 15.53 & 2.45 & 0.53 & 0.13 & 0.88 \\
\hline Alanine aminotransferase, units/L & 13.31 & 11.77 & 12.91 & 12.37 & 0.60 & 0.97 & 0.65 & 0.83 \\
\hline Alkaline phosphatase, units/L & 41.01 & 38.21 & 40.60 & 39.43 & 1.38 & 0.94 & 0.70 & 0.87 \\
\hline
\end{tabular}




\section{Discussion}

Recent studies have shown that dietary supplementation with phytase or protease had positive effects on growth performance of poultry via their specific action $[12,17,18]$. Shirley et al. (2010) have shown that phytase supplementation in diets improved growth performance in broilers [19]. Onyango et al. (2005) also reported that broilers fed diets supplemented with $1000 \mathrm{U} / \mathrm{kg}$ phytase showed improved body weight gain and ADFI [20]. Similar findings were observed by other researchers [21,22], and they reported that dietary supplementation with phytase could improve growth performance of broilers. Meanwhile, Angel et al. (2011) found that the addition of protease improved ADG and F/G of broilers [10]. Freitas et al. (2011) indicated that protease could improve F/G of broilers [23]. In the present study, although it showed no significant difference, meat ducks fed diets supplemented with phytase or protease exhibited numerically higher ADG and ADFI than those fed CON diet. Thus, phytase $A$ and protease A were chosen as the optimal enzyme additives in Experiment 2 on basis of growth performance data from Experiment 1. Growth performance data from Experiment 2 revealed that the addition of phytate and protease combinations leaded to better ADG and final body weight of meat ducks, there was no published research on the effects of phytase and protease combinations on growth performance in meat ducks. The beneficial effects of phytase and protease combined supplementation on ADG and final BW of meat ducks might be associated with the synergistic effect of phytase and protease supplementation. In the present study of Experiment 2, with the dietary supplementation with phytase and protease in lower energy and protein diet, the growth performance could reach to the degree of the higher energy and protein diet but without the addition of phytase and protease, which was in line with the study of Akter et al. (2017) and Cowieson et al. (2019) that phytase and protease supplementation could enhance the feed efficiency and improve growth performance of poultry $[24,25]$. Starch and fatty acid are the main energy supply materials in livestock and poultry, which could chelate with phytate and reduce the energy utilization [26]. Farrell et al. (1993) reported that the addition of phytase could significantly improve the apparent metabolic energy of sorghum-soybean diet [27]. Farrell et al. (1998) similarly indicated that dietary supplementation with phytase could enhance the metabolic energy of meat duck diets [28]. Del Alamo et al. (2008) reported that dietary supplementation with protease could enhance the apparent total tract digestibility of protein in broiler chickens [29]. The phytate molecules of many crops are spherical, which usually are stored in protein-rich tissues (such as germ and aleurone layer), the solubilities of protein and phytate are very similar, resulting in strong chelation between globules of phytate molecules and protein in crops, the addition of phytase could prevent the excessive formation of protein-phytate chelates, even after the formation of protein-phytate chelates, the addition of phytase could also cooperate with pepsin to degrade the protein with maximum efficiency, phytase itself could not hydrolyze protein, so phytase should be combined with pepsin to improve the utilization of protein [30-32]. Thus, we suspected that phytate and protease supplementation had a synergistic effect in the gut due to the preferable digestibility and absorptive environment, which leaded to better growth performance in meat ducks.

The enzyme activities in digestive tract were considered as important factors that could influence intestinal health and nutrient digestibility [33]. Sufficient phytase and protease in the diets are important elements for the digestive system of poultry, as phytase supplementation could increase feed efficiency and gut health $[27,28]$, while protease can affect the intestinal digestive enzymes activities and microbiota of digesta [34]. Protease could increase trypsin and chymotrypsin activities of broiler chicks [35], which was consistent with our results in Experiment 1. Meanwhile, in the present study of Experiment 2, phytase and protease combined supplementation in basal or low-energy and low-protein diet could both significantly increase trypsin and chymotrypsin activities of ducks in the jejunum. Thus, the increased trypsin and chymotrypsin activities by dietary supplementation with protease and phytate may have contributed to the improvement of nutrient digestibility by enhancing ducks' digestive and absorptive function, thus improving growth performance of ducks. Non-starch polysaccharides enzymes (usually xylanase) and phytase can promote each other to improve the utilization of protein and energy in feed and the growth performance of poultry [36]. Phytic acid and 
water-soluble non starch polysaccharide can be closely combined in low-energy diet, which means that non-starch polysaccharide enzyme can more easily approach the surface of phytate and improve the degradation rate of phytate $[36,37]$. Thus, the two functions are complementary in concern respects, thus we suggested protease and phytate may have an interactive effect in the activities of trypsin and chymotrypsin in the intestinal digesta.

The chemical components in serum are mainly composed of the decomposition products in the gut and the metabolites released by tissue cells, which could reflect the accurate metabolic status of the body $[38,39]$. As serum high-density lipoprotein is directly related to metabolism of cholesterol, an enhancement in serum high-density lipoprotein could result in improved lipid metabolism [40]. In the present study, phytase and protease combined supplementation in basal or low energy and protein diet could significantly increase contents of serum high-density lipoprotein, this was in line with the study of Zeafarian et al. (2013), which indicated that addition of phytase could improve lipid metabolism of young broilers [41]. Similarly improved absorptive status of calcium and phosphorus in the body results in decreasing contents of serum calcium and phosphorus [42]. Conversely, the increasing contents of serum calcium and phosphorus means that the absorptive status of calcium and phosphorus in the body is worsen [43]. Previous studies reported that dietary phytase supplementation had lower contents of serum calcium and phosphorus in poultry [44,45], which was in line with our results in Experiment 1. Meanwhile, in the present study of Experiment 2, phytase and protease combined supplementation in basal or low-energy and low-protein diet could significantly increase contents of calcium and phosphorus in the serum, which may mainly result from the addition of phytase.

\section{Conclusions}

In conclusion, dietary supplementation with phytase and protease in different energy and protein diets could increase digestive enzymes in intestinal digesta, effect serum physiochemical parameters, improve metabolic status, and increase growth performance of meat ducks. Meanwhile, with the dietary supplementation with phytase and protease in lower energy and protein diet, the growth performance could reach to the degree of the higher energy and protein diet but without dietary supplementation with phytase and protease. Therefore, our results suggested that phytase and protease could be potential enzyme preparation combinations in low-energy and low-protein diet for improving growth performance, serum metabolism status, and intestinal digestive enzyme activities in meat ducks.

Author Contributions: Conceptualization, J.J., H.W., D.Z. and G.L.; data curation, J.J., H.W. and G.L.; formal analysis, J.J.; funding acquisition, H.W. and G.L.; investigation, J.J., H.W. and G.L.; methodology, J.J., D.Z., J.Y. and J.H.; project administration, H.W. and G.L.; resources, J.J. and G.L.; software, J.J., H.W. and G.L.; supervision, J.J., H.W., S.G. and G.L.; validation, G.L.; writing—Original draft, J.J.; writing—Review and editing, J.J., H.W. and G.L. All authors have read and agreed to the published version of the manuscript.

Funding: This study was supported of Self-funded Research Project of Tongwei Co., Ltd., Chengdu 610041, China.

Acknowledgments: We sincerely acknowledge the assistance of Dengwen Chen and Xianjun Liao for their assistance during the animal experiments and laboratory analyses.

Conflicts of Interest: All authors declare that they have no competing interest in the present work.

\section{References}

1. Humer, E.; Schwarz, C.; Schedle, K. Phytate in pig and poultry nutrition. J. Anim. Physiol. Anim. Nutr. 2015, 99, 605-625. [CrossRef] [PubMed]

2. Selle, P.H.; Cowieson, A.J.; Cowieson, N.P.; Ravindran, V. Protein-phytate interactions in pig and poultry nutrition: A reappraisal. Nutr. Res. Rev. 2012, 25, 1-17. [CrossRef] [PubMed]

3. Amerah, A.M.; Plumstead, P.W.; Barnard, L.P.; Kumar, A. Effect of calcium level and phytase addition on ileal phytate degradation and amino acid digestibility of broilers fed corn-based diets. Poult. Sci. 2014, 93, 906-915. [CrossRef] [PubMed] 
4. Perney, K.M.; Cantor, A.H.; Straw, M.L.; Herkelman, K.L. The effect of dietary phytase on growth performance and phosphorus utilization of broiler chicks. Poult. Sci. 1993, 72, 2106-2114. [CrossRef]

5. Cowieson, A.J.; Acamovic, T.; Bedford, M.R. Phytic acid and phytase: Implications for protein utilization by poultry. Poult. Sci. 2006, 85, 878-885. [CrossRef]

6. Czech, M. Efficacy of phytase in animal diets. Vet. Med. 2007, 63, 1034-1039.

7. Krogdahl, A.; Sell, J.L. Influence of age on lipase, amylase, and protease activities in pancreatic tissue and intestinal contents of young turkeys. Poult. Sci. 1989, 68, 1561-1568. [CrossRef]

8. Raul, F.; Gosse, F.; Doffoel, M.; Darmenton, P.; Wessely, J.Y. Age related increase of brush border enzyme activities along the small intestine. Gut 1998, 29, 1557-1563. [CrossRef]

9. Mahmood, T.; Mirza, M.A.; Nawaz, H.; Shahid, M. Exogenous protease supplementation of poultry by-product meal-based diets for broilers: Effects on growth, carcass characteristics and nutrient digestibility. J. Anim. Physiol. Anim. Nutr. 2018, 102, e233-e241. [CrossRef]

10. Angel, C.R.; Saylor, W.; Vieira, S.L.; Ward, N. Effects of a monocomponent protease on performance and protein utilization in 7- to 22-day-old broiler chickens. Poult. Sci. 2011, 90, 2281-2286. [CrossRef]

11. Rubio, L.A.; Brenes, A.; Centeno, C. Effects of feeding growing broiler chickens with practical diets containing sweet lupin (Lupinus angustifolius) seed meal. Br. Poult. Sci. 2003, 44, 391-397. [CrossRef] [PubMed]

12. Cowieson, A.J.; Roos, F.F. Bioefficacy of a mono-component protease in the diets of pigs and poultry: A meta-analysis of effect on ileal amino acid digestibility. J. Appl. Anim. Nutr. 2013, 2, e13. [CrossRef]

13. Zenella, L.; Sakomura, N.K.; Silversides, F.G.; Fiqueirdo, A.; Pack, M. Effect of enzyme supplementation of broiler diets based on corn and soybeans. Poult. Sci. 1999, 78, 561-568. [CrossRef] [PubMed]

14. Wu, D.; Wu, S.B.; Choct, M.; Swick, R.A. Comparison of 3 phytases on energy utilization of a nutritionally marginal wheat-soybean meal broiler diet. Poult. Sci. 2015, 94, 2670-2676. [CrossRef]

15. Shahir, M.H.; Rahimi, R.; Taheri, H.R.; Heidariniya, A.; Baradaran, N.; Asadi, K.Z. Effect of protein source and protease addition on performance, blood metabolites and nutrient digestibility of turkeys fed on low-protein diets from 28 to 55 d post hatch. Br. Poult. Sci. 2016, 57, 390-396. [CrossRef]

16. NRC. Nutrient Requirements of Poultry, 9th Revised ed.; National Academies Press: Washington, DC, USA, 1994.

17. Srefanello, C.; Vieira, S.L.; Santiago, G.O.; Kindlein, L.; Sorbara, J.O.; Cowieson, A.J. Starch digestibility, energy utilization, and growth performance of broilers fed corn-soybean basal diets supplemented with enzymes. Poult. Sci. 2015, 94, 2472-2479. [CrossRef]

18. Cowieson, A.J.; Ptak, A.; Mackowiak, P.; Sassek, M.; Praszunska-Oszmalek, E.; Zyla, K.; Swiatkiewicz, S.; Kaczmarek, S.; Józefiak, D. The effect of microbial phytase and myo-inositol on performance and blood biochemistry of broiler chickens fed wheat/corn-based diets. Poult. Sci. 2013, 92, 2021-2134. [CrossRef]

19. Shirley, R.B.; Edwards, H.M., Jr. Graded levels of phytase past industry standards improves broiler performance. Poult. Sci. 2003, 82, 671-680. [CrossRef]

20. Onyango, E.M.; Bedford, M.R.; Adeola, O. Efficacy of an evolved Escherichia coli phytase in diets of broiler chicks. Poult. Sci. 2005, 84, 248-255. [CrossRef]

21. Pirgozliev, V.; Oduguwa, O.; Acamovic, T.; Bedford, M.R. Diets containing Escherichia coli-derived phytase on young chickens and turkeys: Effects on performance, metabolizable energy, endogenous secretions, and intestinal morphology. Poult. Sci. 2007, 86, 705-713. [CrossRef]

22. Selle, P.; Ravindran, V. Microbial phytase in poultry nutrition. Anim. Feed Sci. Technol. 2007, 135, 1-41. [CrossRef]

23. Freitas, D.M.; Angel, C.R.; Maiorka, A. Performance and nutrient utilization of broilers fed diets supplemented with a novel mono component protease. J. Appl. Poult. Res. 2011, 20, 322-334. [CrossRef]

24. Akter, M.; Lji, P.A.; Graham, H. Increased iron level in phytase-supplemented diets reduces performance and nutrient utilisation in broiler chickens. Br. Poult. Sci. 2017, 58, 409-417. [CrossRef] [PubMed]

25. Cowieson, A.J.; Toghyani, M.; Kheravii, S.K.; Wu, S.B.; Romero, L.F.; Choct, M. A mono-component microbial protease improves performance, net energy, and digestibility of amino acids and starch, and upregulates jejunal expression of genes responsible for peptide transport in broilers fed corn/wheat-based diets supplemented with xylanase and phytase. Poult. Sci. 2019, 98, 1321-1332.

26. Harland, B.F.; Morris, E.R. Phytate: A good or a bad food component? Nutr. Res. 1995, 15, 733-754. [CrossRef] 
27. Farrell, D.J.; Martin, E.A.; Du Preez, J.J.; Bongarts, M.; Betts, M.; Sudarman, A.; Thomson, E. The beneficial effects of a microbial feed phytase in diets of broiler chickens and ducklings. J. Anim. Physiol. Anim. Nutr. 1993, 69, 278-283. [CrossRef]

28. Farrell, D.J.; Martin, E.A. Strategies to improve the nutritive value of rice bran in poultry diets. III. The addition of inorganic phosphorus and a phytase to duck diets. Br. Poult. Sci. 1998, 39, 601-611. [CrossRef]

29. Del Alamo, A.G.; Verstegen, M.W.A.; Den Hartog, L.A.; De Ayala, P.P.; Villamide, M.J. Effect of Wheat Cultivar and Enzyme Addition to Broiler Chicken Diets on Nutrient Digestibility, Performance, and Apparent Metabolizable Energy Content. Poult. Sci. 2008, 87, 759-767. [CrossRef]

30. Selle, P.; Ravindran, V.; Caldwell, A.; Bryden, W.L. Phytate and phytase: Consequences for protein utilization. Nutr. Res. Rev. 2001, 13, 255-278. [CrossRef]

31. Boling-Frankenbach, S.D.; Peter, C.M.; Dougal, M.W.; Snow, J.; Parsons, C.M.; Baker, D.H. Efficacy of phytase for increasing protein efficiency ratio values of feed ingredients. Poult. Sci. 2001, 80, 1578-1584. [CrossRef]

32. Selle, P.; Ravindran, V. Phytate-degrading enzymes in pig nutrition. Livest. Sci. 2008, 113, 99-122. [CrossRef]

33. Pettersson, D.; Aman, P. Enzyme supplementation of a poultry diet containing rye and wheat. Br. J. Nutr. 1989, 62, 139-149. [CrossRef] [PubMed]

34. Walk, C.L.; Pirgozliev, V.; Juntunen, K.; Paloheimo, M.; Ledoux, D.R. Evaluation of novel protease enzymes on growth performance and apparent ileal digestibility of amino acids in poultry: Enzyme screening. Poult. Sci. 2018, 62, 2123-2138. [CrossRef] [PubMed]

35. Shapiro, F.; Nir, L. Stunting syndrome in broilers: Effect of age and exogenous amylase and protease on performance, development of the digestive tract, digestive enzyme activity, and apparent digestibility. Poult. Sci. 1995, 74, 2019-2028. [CrossRef]

36. Gehring, C.K.; Bedford, M.R.; Dozier, W.A. Interactive effects of phytase and xylanase supplementation with extractable salt-soluble protein content of corn in diets with adequate calcium and nonphytate phosphorus fed to broilers. Poult. Sci. 2013, 92, 1858-1869. [CrossRef]

37. Wu, Y.B.; Ravindran, V.; Thomas, D.G.; Birtles, M.J.; Hendriks, W.H. Influence of phytase and xylanase, individually or in combination, on performance, apparent metabolisable energy, digestive tract measurements and gut morphology in broilers fed wheat-based diets containing adequate level of phosphorus. Br. Poult. Sci. 2004, 45, 76-84. [CrossRef]

38. Sullivan, M.J.; Lackner, L.H.; Banowsky, L.H.W. Intraperitoneal extravasation of urine: BUN/serum creatinine disproportion. J. Am. Med. Assoc. 1972, 221, 491-492. [CrossRef]

39. Casal, N.; Manteca, X.; Peña, R.; Bassols, A.; Fàbrega, E. Analysis of cortisol in hair samples as an indicator of stress in pigs. J. Vet. Behav. 2017, 19, 1-6. [CrossRef]

40. Singh, I.M.; Shishehbor, M.H.; Ansell, B.J. High-density lipoprotein as a therapeutic target: A systematic review. J. Am. Med. Assoc. 2007, 298, 786-798. [CrossRef]

41. Zeafarian, F.; Romero, L.F.; Ravindran, V. Influence of a microbial phytase on the performance and the utilisation of energy, crude protein and fatty acids of young broilers fed on phosphorus-adequate maize- and wheat-based diets. Br. Poult. Sci. 2013, 54, 653-660. [CrossRef]

42. Deluca, H.F. The Vitamin D system in the regulation of calcium and phosphorus metabolism. Nutr. Rev. 1979, 37, 161-193. [CrossRef] [PubMed]

43. Brot, C.; Jørgensen, N.; Madsen, O.R.; Jensen, L.B.; Sørensen, O.H. Relationships between bone mineral density, serum vitamin D metabolites and calcium: Phosphorus intake in healthy perimenopausal women. J. Int. Med. 1999, 245, 509-516. [CrossRef] [PubMed]

44. Gautier, A.E.; Walk, C.L.; Dilger, R.N. Effects of a high level of phytase on broiler performance, bone ash, phosphorus utilization, and phytate dephosphorylation to inositol. Poult. Sci. 2018, 97, 211-218. [CrossRef] [PubMed]

45. Mitchell, R.D.; Edwards, H.M. Effects of phytase and 1,25-dihydroxycholecalciferol on phytate utilization and the quantitative requirement for calcium and phosphorus in young broiler chickens. Poult. Sci. 1996, 75, 95-110. [CrossRef] [PubMed]

(C) 2020 by the authors. Licensee MDPI, Basel, Switzerland. This article is an open access article distributed under the terms and conditions of the Creative Commons Attribution (CC BY) license (http://creativecommons.org/licenses/by/4.0/). 